\section{Enhanced Production of Fattiviracins by Bacitracin-resistant Strains of Streptomyces microflavus Strain No. 2445}

Sir:

Streptomycetes are soil microorganisms that produce a high proportion of medically important antibiotics. Many antibiotics with a variety of chemical structures and biological activities have been found from streptomycetes as their secondary metabolites. The improvement of Streptomyces strains with respect to antibiotics production is industrially and economically important for clinical use. Many mutations have been introduced into Streptomyces strains to enhance the production of a particular antibiotic.

Fattiviracins produced by Streptomyces microflavus strain No. 2445 isolated in our laboratories are potent antiviral agents effective for herpes simplex virus type 1 (HSV-1), varicella-zoster virus (VZV), human immunodeficiency virus type 1 (HIV-1) and influenza $\mathrm{A}$ and $\mathrm{B}$ viruses in vitro $^{1,2)}$. Fattiviracins belong to sugar-fatty acid lactone, which have macrocyclic diesters formed by the binding of two trihydroxyfatty acids and four D-glucose residues in the molecule. They are divided in thirteen components by difference of the length of fatty acids and stereoisomer ${ }^{3}$. The purification procedure for thirteen components of fattiviracins is conducted finally with the repeated preparative HPLC. To obtain large quantity of the compounds efficiently, the improvement of their productivity and purification is required. If this producing strain produced only a few components of fattiviracins, the purification procedure would become simple. In this study we demonstrate that Streptomyces microflavus strain No. 2445 acquired resistance for bacitracin (BC) shows significantly quantitative and qualitative alterations in the production of fattiviracins.

Minimum inhibitory concentrations (MIC) of BC to Streptomyces microflavus strain No. 2445 (the wild strain) was determined by Waksman's agar dilution streak method $^{4)}$ using MGA agar plates consisting of glucose $1.0 \%$, asparagine $0.05 \%, \mathrm{~K}_{2} \mathrm{HPO}_{4} 0.05 \%$, yeast extract $0.05 \%$, and agar $1.5 \%$, at $\mathrm{pH} 7.0$. MIC of the wild strain to $\mathrm{BC}$ was $10 \mu \mathrm{g} / \mathrm{ml}$. The spontaneous BC-resistant mutants of the wild strain were obtained as resistant colonies that grew within 10 days, after spores were spread on MGA agar plates containing BC. Spores generated on the MGA agar plate containing the highest concentration of $\mathrm{BC}$ were transferred onto MGA agar plates containing the higher concentrations of $\mathrm{BC}$. This cultivation was repeatedly carried out to generate $\mathrm{BC}$ resistance. After 5 to 6 transfers onto MGA agar plates containing the raising concentrations of BC, BC-resistant strains (BCR) designated as 40-BCR, 120-BCR and 350-BCR grown on the plates containing 40, 120 and $350 \mu \mathrm{g} / \mathrm{ml}$ of $\mathrm{BC}$, respectively, were obtained. Spore mass color of the strain grown on MGA agar containing $\mathrm{BC}$ upto $20 \mu \mathrm{g} / \mathrm{ml}$ was observed as the same brownish gray as that of the wild strain, however, that of 40-BCR was gray, and those of BCR grown on MGA agar containing 60 to $350 \mu \mathrm{g} / \mathrm{ml}$ of $\mathrm{BC}$ turned to white. $\mathrm{BC}$-resistant strains were stored at $5^{\circ} \mathrm{C}$ after cultivation on MGA agar slants containing the same resistant concentration of $\mathrm{BC}$ at $28^{\circ} \mathrm{C}$ for 2 weeks.

Comparison of the wild strain and 40-BCR with respect to fattiviracins production was examined. The antiviral activities of culture filtrate against HSV-1 were measured by a plaque reduction assay ${ }^{5}$. The residual glucose in the cultures was determined by Somogyi-Nelson method ${ }^{6)}$. As shown in Fig. 1, the antiviral activities of the wild strain and 40-BCR were 134 and 280 unit/ml after 6 days cultivation, respectively. It showed that $40-\mathrm{BCR}$ produced fattiviracins 2.1 -fold more than the wild strain. The mycelium growth of 40-BCR was 1.3-fold higher than that of the wild strain after 6 days cultivation (Fig. 1). The utilization of glucose in the cultures was no difference between them. The patterns of antiviral activity of culture filtrate and mycelium growth among 40-BCR, 120-BCR and $350-\mathrm{BCR}$ were almost the same (Fig. 2). From this result, $40 \mu \mathrm{g} / \mathrm{ml}$ of $\mathrm{BC}$-resistant concentration was thought to be enough for the acquisition of higher fattiviracins production.

To investigate the fattiviracin components produced by the wild strain and 40-BCR, $500 \mathrm{ml}$ of the 6 days cultures were partially purified and $167 \mathrm{mg}$ and $34 \mathrm{mg}$ of crude samples containing fattiviracin components were obtained, respectively. Purification of fattiviracins was described in our preceding paper ${ }^{3)}$. Fattiviracin components in the crude sample were analyzed with an analytical HPLC (column: $\mu$ Bondapak $\mathrm{C}_{18}$, Waters Associates, $4.6 \times 150 \mathrm{~mm}$, mobile phase: $90 \% \mathrm{MeOH}$, flow rate: $0.42 \mathrm{ml} /$ minute, detection: $\mathrm{OD}$ at $210 \mathrm{~nm}$ ). As shown in Fig. 3, the different patterns of 
Fig. 1. Antiviral activity and cell growth of wild strain and BC-resistant strain (40-BCR) of strain No. 2445.

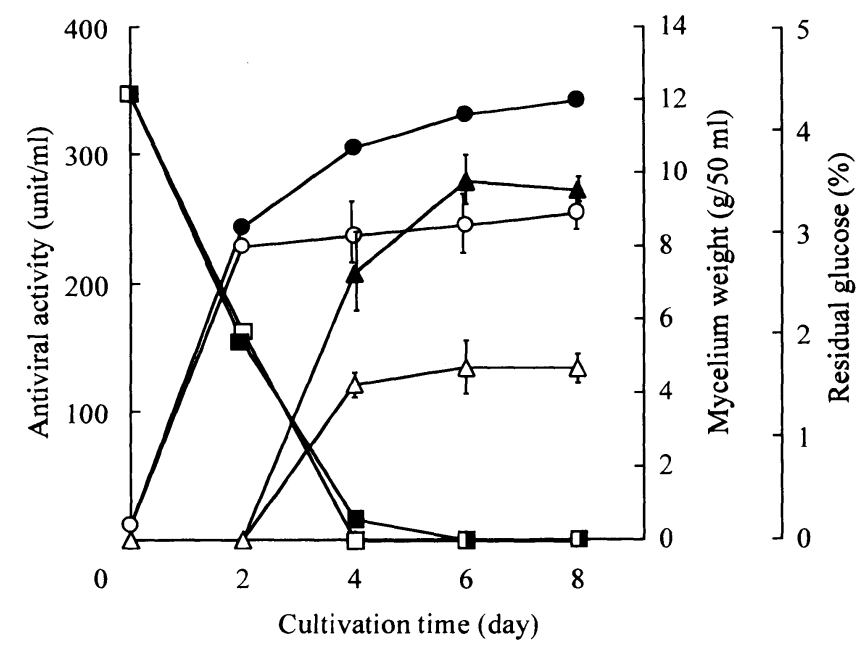

Wild strain and $40-\mathrm{BCR}$ were incubated at $28^{\circ} \mathrm{C}$ on a rotary shaker set up at $180 \mathrm{rpm}$. Mycelium weight: $\bigcirc$, wild strain;, $40-B C R$. Antiviral activity: $\triangle$, wild strain; $\boldsymbol{\Delta}, 40-\mathrm{BCR}$. Residual glucose: $\square$, wild strain; 口, 40-BCR.

Fig. 2. Antiviral activity and cell growth of 40-BCR, 120-BCR and 350-BCR.

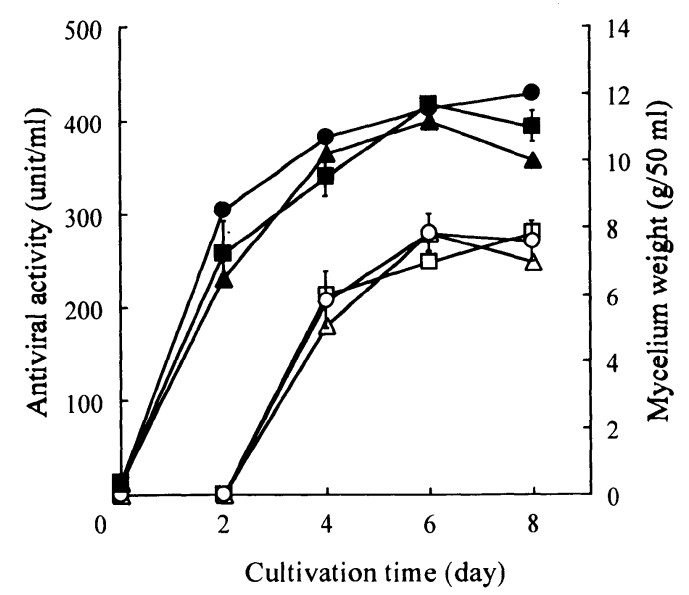

Mycelium weight: $-40-\mathrm{BCR}$; , 120-BCR; 350-BCR. Antiviral activity: $O, 40-B C R ; \triangle, 120-$ BCR; $\square, 350-$ BCR.

fattiviracin components produced by them were observed. Especially, 40-BCR produced exclusively fattiviracin FV13 , which accounted for approximately $68 \%$ of the total
Fig. 3. HPLC profiles of the fattiviracin components in the culture filtrate from wild strain (A) and 40-BCR (B).

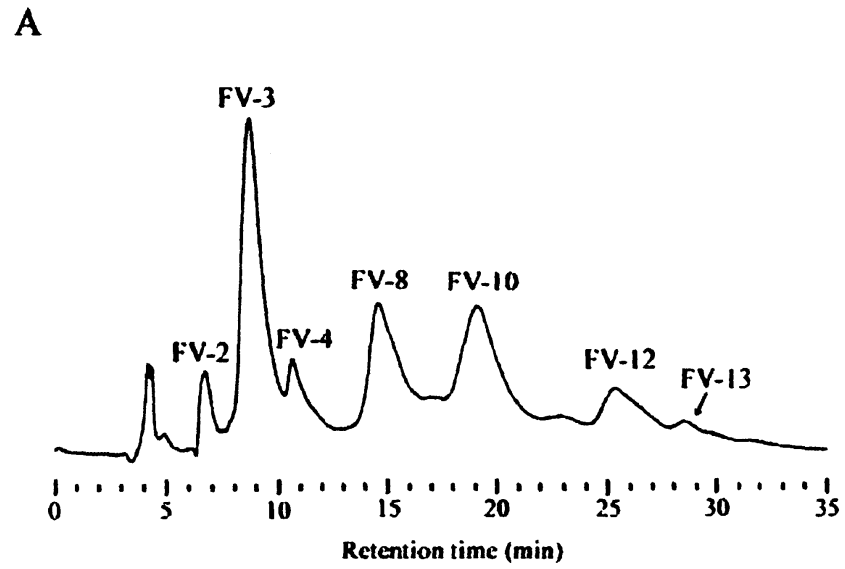

B

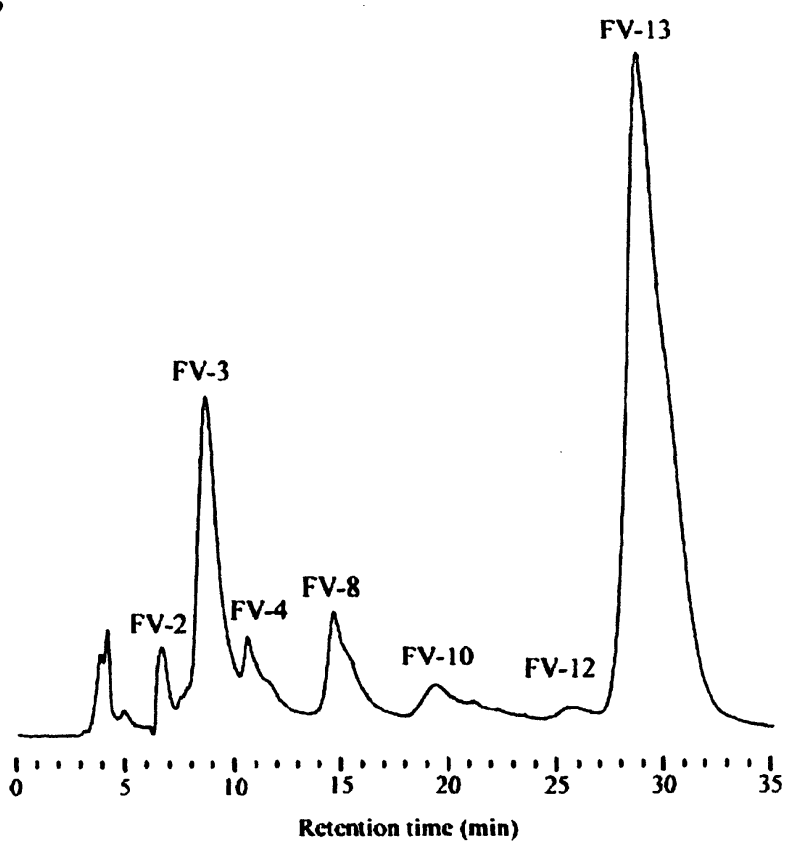

fattiviracin components. On the other hand, the amounts of fattiviracin FV-10 and FV-12 were decreased in the 40-BCR culture. These results suggest that the fattiviracinsproducing strain acquired resistance for bacitracin has the ability of the higher and astringent productivity of fattiviracin $\mathrm{FV}-13$.

The regulation of the length of fatty acids moiety in fattiviracin molecule is important for the astringent production of fattiviracins. We considered BC-resistant mutation which might regulate the membrane lipid metabolism in the fattiviracins-producing strain, would 
influence the production of fattiviracins. The development of fattiviracins as an antiviral drug was difficult for the large-scale preparation because of the low productivity and the existence of thirteen derivatives of fattiviracin. However, BC-resistant strain (40-BCR) exhibits the higher productivity and, in addition, the astringent productivity of fattiviracin FV-13 which has the highest molecular weight among fattiviracin components. The large scale preparation of fattiviracin FV-13 is now undergoing with the 40-BCR. Also the strains acquired resistance for higher concentration of bacitracin (120-BCR and 350-BCR) will be studied on their astringent productivity.

The mechanism of resistance of the fattiviracinsproducing strain to $\mathrm{BC}$ has not been studied. Bacitracin is one of the inhibitors of cell wall biosynthesis of bacteria. By binding to the $\mathrm{C}_{55}$-isoprenyl pyrophosphate in the presence of a divalent cation, bacitracin prevents the formation of $\mathrm{C}_{55}$-isoprenyl phosphate. $\mathrm{C}_{55}$-isoprenyl pyrophosphate functions as a lipid carrier for the transport across the membrane of the disaccharide-pentapeptide subunits of the peptidoglycan cell wall ${ }^{7)}$. In the bacitracin-resistant strains of Escherichia coli, Streptococcus pneumoniae and Staphylococcus aureus, when membrane-associated isoprenol kinase encoded in the bacA gene is overproduced, it is able to produce sufficient supplies of $\mathrm{C}_{55}$-isoprenyl phosphate from $\mathrm{C}_{55}$-isoprenol to overcome the effects of $\mathrm{C}_{55}$-isoprenyl pyrophosphate sequestration, thereby causing bacitracin resistance ${ }^{8,9)}$. In the bacitracin-resistant strain of Streptomyces microflavus strain No. 2445, the possibility of an increase in $\mathrm{C}_{55^{-}}$ isoprenyl phosphate or the activation of isoprenol kinase that may be related with the biosynthesis of fatty acid moieties in FV-13 molecule is now under investigation.

\author{
MASARU UYEDA \\ TAKAHIRO NAGATA \\ KAZUMI YOKOMIZO \\ TOMONORI MATSUMOTO \\ HIROKI TODA \\ Keitarou Suzuki
}

Department of Pharmaceutical Microbiology,

Faculty of Medical and Pharmaceutical Sciences, Kumamoto University,

5-1 Oe-Honmachi, Kumamoto, 862-0973, Japan

(Received July 1, 2003)

\section{References}

1) Uyeda, M.; K. Yokomizo, Y. Miyamoto \& E. Habiв: Fattiviracin A1, a novel antiherpetic agent produced by Streptomyces microflavus strain No. 2445. I. Taxonomy, fermentation, isolation, physico-chemical properties and structure elucidation. J. Antibiotics 51: 823 828, 1998

2) Habib, E.; K. Yokomizo, K. NagaO, S. Harada \& M. UYEDA: Antiviral activity of fattiviracin FV-8 against human immunodefiency virus type 1 (HIV-1). Biosci. Biotechnol. Biochem. 65: 683 685, 2001

3) Haвiв, E.; K. Yokomizo, K. Murata \& M. Uyeda: Structures of fattiviracin family, antiviral antibiotics. J. Antibiotics 53: 1420 1423, 2000

4) Waksman, S. A. \& H. C. Reily: Agar-streak method for assaying antibiotic substance. Ind. Eng. Chem., Anal. Ed. 17: 556 557, 1945

5) Boyd, M. R.; T. H. Bacon, D. Sutton \& M. Cole: Antiherpesvirus activity of 9-(4-hydroxy-3hydroxymethylbut-1-yl) guanine (BRL39123) in cell culture. Antimicrob. Agents Chemother. 31: 1238 1242, 1987

6) Somogyi, M.: Notes on sugar determination. J. Biol. Chem. 195: 19 23, 1952

7) Stone, K. J. \& J. L. Strominger: Mechanism of action of bacitracin: complexation with metal ion and $\mathrm{C}_{55^{-}}$ isoprenyl pyrophosphate. Proc. Natl. Acad. Sci. USA 68: 3223 3227, 1971

8) Cain, B. D.; P. J. Norton, W. Eubanks, H. S. Nick \& C. M. Allen: Amplification of the bacA gene confers bacitracin resistance to Escherichia coli. J. Bacteriol. 175: 3784 3789, 1993

9) Chalker, A. F; K. A. Ingraham, R. D. Lunsford, A. P. Bryant, J. Bryant, N. G. Wallis, J. P. Broskey, S. C. PeARson \& D. J. Holmes: The bacA gene, which determines bacitracin susceptibility in Streptococcus pneumoniae and Staphylococcus aureus, is also required for virulence. Microbiology 146: 1547 1553, 2000

\footnotetext{
* Corresponding author: uyeda@gpo.kumamoto-u.ac.jp
} 